Przegląd Prawa Konstytucyjnego

- -ISSN 2082-1212--------

DOI 10.15804/ppk.2016.01.10

$-\mathrm{Nr} 1(29) / 2016-------$

\title{
Recenzja
}

\section{Marcin Konarski, Marek Woch, Ewolucja prawa miejscowego jednostek samorzadu terytorialnego w Polsce, Wydawnictwo Marek Woch, Warszawa 2014, ss. 251}

Recenzowana pozycja należy do ciekawszych książek, które ukazały się w ostatnim czasie na rynku wydawniczym. Zgodnie z deklaracją Autorów stanowić ma studium o charakterze historyczno-porównawczym. Niewątpliwie można ją potraktować jako uzupełnienie badań prowadzonych już $\mathrm{w}$ doktrynie prawa administracyjnego ${ }^{1}$ oraz incydentalnie $\mathrm{w}$ doktrynie prawa konstytucyjnego ${ }^{2}$. Stąd też w zamyśle Autorów analiza aktualnego stanu konstytucyjnego nie jest szczegółowa i zawiera uwagi o podstawowym, niezbędnym zakresie. Intencją M. Konarskiego i M. Wocha było bowiem skierowanie jej do studentów, którzy mają być główną grupą odbiorców dzieła. Wydaje się jednak, że nie mamy do czynienia z podręcznikiem, lecz opracowaniem uzupełniającym zdobytą wiedzę.

Uwagi dotyczące monografii pragnę rozpocząć od tytułu. Jest on dość rozbudowany, co najczęściej stanowi mankament opracowań. W przypadku recenzowanej pozycji rozbudowany tytuł oddaje jednak w precyzyjny sposób wybrane

\footnotetext{
D. Dąbek, Prawo miejscowe, Warszawa 2007.

2 A. Bień-Kacała, Źródła prawa samorządowego w Konstytucji RP, [w:] Podstawy wolności zrzeszania się oraz zasada samorządności w prawie konstytucyjnym Polski i Ukrainy, red. W. Skrzydło, W. Szapował, K. Eckhardt, P. Steciuk, Rzeszów-Przemyśl 2013, czy J. Ciapała, Prawo miejscowe, [w:] Zarys prawa samorzadu terytorialnego, red. M. Ofiarska, J. Ciapała, Poznań 2001.
} 
przez Autorów pole badawcze. Z uwagi na to, że pod konstytucyjnym pojęciem prawa miejscowego kryją się dwie zasadnicze grupy aktów, tytuł zapowiada analizę jednej z nich. Autorzy skupili się bowiem na kategorii prawa miejscowego samorządu terytorialnego, pozostawiając poza zakresem ich zainteresowania prawo miejscowe terenowych organów administracji rządowej.

Praca składa się z trzech rozdziałów. Pod względem formalnym zostały podzielone na odpowiednie proporcjonalne części. Niemniej jednak ostatni rozdział dotyczący obowiązującej Konstytucji jest najkrótszy, a co za tym idzie najmniej szczegółowy. Wydaje się, że powinien być on nieco bardziej rozbudowany. Aktualne bowiem stadium rozwoju ewolucyjnego powinno zostać omówione najbardziej szczegółowo. Nadaje to właściwy sens ujęcia tematu w sposób ewolucyjny, nie zaś historyczny. Tej uwagi nie niweluje przyjęta przez Autorów perspektywa historyczne oraz dydaktyczna. Całościowy natomiast walor recenzowanej pozycji polega na uzupełnieniu badań teoretycznych nad samymi źródłami prawa oraz samorządem terytorialnym z historycznej perspektywy.

W pierwszym rozdziale $\mathrm{M}$. Konarski i $\mathrm{M}$. Woch zawarli teoretyczne relacje prawa miejscowego w systemie prawa stanowionego. Rozpoczęli od teoretycznego ujęcia samorządu terytorialnego oraz ogólnych zagadnień legislacji. Samorząd terytorialny łączony jest przede wszystkim z władztwem państwowym i zdecentralizowaną formą administracji publicznej. Z drugiej strony omówione zostały także koncepcje rozpoznające gminę jako byt pierwotny względem państwa i od niego niezależny. Rozważania uzupełnione zostały szczegółową analizą pojęcia samorządu terytorialnego na podstawie Konstytucji RP z 1997 r. Łączy się on z kwestią suwerenności państwowej oraz możliwością udzielenia części władztwa państwowego innym podmiotom, w tym samorządowi terytorialnemu. Następnie Autorzy sięgnęli do teoretycznych podstaw delegowania kompetencji prawotwórczej. Zaprezentowali przy tym szerokie spektrum poglądów w tej materii. Rozprawili się również z kategorią decentralizacji. Rozważania prowadzone są przez kwestię braku hierarchicznego podporządkowania. Analizie poddany został także problem autonomii, którą Autorzy skonfrontowali z pozycją prawną samorządu terytorialnego. W zakresie systemu źródeł prawa szeroko omówione zostały kategorie przepisu prawa i normy prawnej. Szkoda tylko, że Autorzy nie uzasadnili potrzeby takiego rozróżnienia w odniesieniu do prawa samorzą- 
dowego. W odniesieniu do osadzania aktów prawa miejscowego samorządu terytorialnego w ramach systemu źródeł prawa M. Konarski i M. Woch dokonali krótkiej analizy zagadnienia, odwołując się do uregulowań konstytucyjnych. Omówienie to, choć poprawne merytorycznie, wydaje się zbyt syntetyczne. Warto byłoby tę analizę poszerzyć w następnym wydaniu książki.

Drugi rozdział poświęcony został właściwej analizie historycznej prawa miejscowego $\mathrm{w}$ polskim porządku prawnym. Autorzy rozpoczęli wywód od źródeł polskiej państwowości. W początkowej części rozdziału mamy do czynienia z omówieniem głównie rozwoju samorządu, nie zaś prawa przezeń stanowionego. Wydaje się, że sięgnięto tu nazbyt „głęboko” aż do państwa feudalnego, a nawet do okresu p.n.e. Interesująco przedstawiona została natomiast kwestia końca autonomii miast w XVII w. oraz rozrostu administracji państwowej. Autorzy wskazali, że miało to negatywne przełożenie na rozwój prawotwórstwa lokalnego. Następnie przeszli do myśli prawno-ustrojowej u schyłku I Rzeczypospolitej. Kwestie te zostały zaprezentowane interesująco, niemniej jednak nie wskazano należycie związków merytorycznych z tematem opracowania. Następnie M. Konarski i M. Woch omówili stan prawny w okresie międzywojennym. Część ta zawiera ciekawe rozważania i pokazuje kompetencje Autorów niezbędne do rzeczowego omówienia skomplikowanej normatywnie sytuacji u progu porozbiorowej państwowości polskiej. Ponadto Autorzy umiejętnie osadzili analizę w aktualnych historycznie poglądach doktryny. W kontekście rozważań historycznych można wysnuć wniosek, że samorządność jest stałym elementem rozwoju wspólnot miejscowych. Chronologia wymagała przedstawienia badań dotyczących okresu Polskiej Rzeczypospolitej Ludowej. Słusznie Autorzy podkreślają upaństwowienie ogniw struktury państwa w warunkach jednolitości władzy państwowej. Prawo stanowione lokalnie nie miało wówczas charakteru samorządowego. W okresie transformacji ustrojowej najważniejsze, w kontekście tematu opracowania, było reaktywowanie samorządu terytorialnego i uchwalenie w 1990 r. stosownej ustawy o samorządzie terytorialnym ${ }^{3}$. Przy czym Autorzy poświęcili sporo miejsca na omówienie unormowań w niej zawartych. Kwestie prawotwórstwa lokalnego zostały natomiast omówione raczej w wąskim zakresie.

3 Ustawa z 8 marca 1990 r. o samorządzie terytorialnym (Dz.U. Nr 16, poz. 95). 
W trzecim rozdziale mamy do czynienia z przedstawieniem prawa miejscowego samorządu terytorialnego w świetle Konstytucji RP z 1997 r. Autorzy uzupełnili omówienie przepisów konstytucyjnych warstwą ustawową. W pierwszej kolejności zaprezentowana została kwestia rodzajów aktów prawa miejscowego. Główną grupą są akty wykonawcze. Doniosłe znaczenie posiadają natomiast źródła prawa o ustrojowym charakterze, zwłaszcza statutowe. Szkoda, że tym ostatnim Autorzy nie poświęcili więcej zainteresowania, zwłaszcza jeśli idzie o podstawę prawną (konstytucja czy ustawa) ich stanowienia. Oddzielny rodzaj aktów stanowią niedocenianie przepisy porządkowe ${ }^{4}$. I tym razem analiza nie jest jednak przesadnie rozbudowana. Następnie Autorzy skupili się na wskazaniu podmiotów posiadających kompetencję prawotwórczą w odniesieniu do prawa miejscowego. Słusznie odnotowali, że kompetencja ta przypisana została na poziomie ustawowym nie tylko organom stanowiącym, ale także samorządowym organom wykonawczym. Omówiono również procedurę stanowienia interesujących nas źródeł prawa. Nie uszła uwadze M. Konarskiego i M. Wocha kwestia ogłaszania aktów normatywnych. Autorzy poświęcili także znaczną część rozważań kontroli aktów prawa miejscowego. Przedstawienie wskazanych zagadnień wpłynęło na uzyskanie efektu krótkiego, lecz całościowego omówienia tytułowego zagadnienia.

Wymaganiem recenzyjnym jest zwrócenie uwagi na pewne niedociągnięcia pracy, jeśli takie występują. Przeważnie zaś występują, gdyż jak wiadomo dzieło ludzkie rzadko jest doskonałe. Potknięć nie ustrzegli się także Autorzy książki. Pewną niezręcznością jest oczywiście posługiwanie się skrótowcami na początku zdania, czy kończenie zdań w taki sposób, że na ich końcu dochodzi do kumulacji dwóch kropek. Poważnym mankamentem jest natomiast brak zakończenia, wniosków czy podsumowania pracy. W pracy o charakterze porównawczym takie merytoryczne uwagi są niezbędne do wskazania podobieństw i różnic porównywanych elementów. Niestety z dość krótkiego słowa wstępnego nie pozyskujemy wiedzy co do comparatum (składników materiału do porównania), a choćby ze zwięzłego zakończenia co do comparandum (rezultatu porównania). W opracowaniu brakuje

4 O ich znaczeniu wypowiedział się Trybunał Konstytucyjny choćby w wyroku z 20 maja 2014 r. (K 17/13), por. A. Bień-Kacała, Glosa do wyroku Trybunału Konstytucyjnego z 20 maja 2014 r. (K 17/13), „Przegląd Sejmowy” 2014, nr 6, s. 157-164. 
nie tylko zakończenia, ale również merytorycznych wniosków porównawczych. Mankamentu tego nie znosi wybrana technika podsumowań poszczególnych rozdziałów, choć niewątpliwie łagodzi krytykę w tym zakresie.

Pomimo tych kilku uwag krytycznych należy uznać recenzowaną pozycję za ważną na polskim rynku wydawniczym w zakresie literatury konstytucyjnoprawnej. Tym bardziej, że wydanie monografii dotyczącej prawa miejscowego wpisuje się w podsumowanie okresu ćwierćwiecza samorządu terytorialnego. Bez recenzowanego opracowania ocena tego okresu działania samorządu w Polsce byłaby niepełna. W tym właśnie kryje się wartość książki autorstwa M. Konarskiego i M. Wocha zatytułowanej Ewolucja prawa miejscowego jednostek samorządu terytorialnego w Polsce.

Agnieszka Bień-Kacała Uniwersytet Mikołaja Kopernika w Toruniu 